\title{
UVODNIK
}

\section{RAZISKAVA PIAAC - VPOGLED V SEDANJE SPRETNOSTI ODRASLIH}

Slovenija se je v začetku leta 2013 vključila v drugi krog mednarodne raziskave PIAAC (Program za mednarodno ocenjevanje kompetenc odraslih), ki poteka v okviru OECD, rezultate pričakujemo sredi leta 2016. PIAAC velja za največjo empirično raziskavo na področju izobraževanja odraslih v svetovnem merilu po številu vključenih posameznikov, za inovativno glede na raziskovalni instrumentarij, za kompleksno glede na vzorčni načrt in metodologijo izpeljave, za transparentno po dostopnosti rezultatov in baz podatkov široki javnosti ter za kontroverzno po vprašanjih, ki jih odpira tako pri raziskovalcih in izobraževalcih odraslih kot tudi pri načrtovalcih politik. Zbrana baza podatkov bo ena najbogatejših baz podatkov sploh in bo omogočila številne primerjave, analize ter navzkrižne študije. Razumljivo je, da so tudi v strokovni in splošni javnosti velika pričakovanja glede tega, kaj bo raziskava pokazala za Slovenijo, še posebej zaradi tega, ker spremljamo manj ugodne rezultate bralne pismenosti mladih v raziskavi PISA. Dovolj poznani pa so tudi neugodni rezultati predhodne raziskave pismenosti odraslih, v kateri je Slovenija sodelovala leta 1998.

Težave povzroča razumevanje tega, kar preučuje raziskava, bodisi zato, ker se sprašujemo, zakaj se svetovna raziskava ukvarja z merjenjem tako preprostih stvari, kot so branje in razumevanje, računanje za vsakdanje potrebe in nekoliko zahtevnejša uporaba interneta. Pogosteje pa zavoljo tega, ker se v strokovnih besedilih pojavlja več terminov za to, kar preučuje raziskava. Na prvo dilemo bo odgovorila raziskava sama z rezultati za Slovenijo. Strokovna literatura o izobraževanju in usposabljanju razlikuje med »kompetenco« in »spretnostjo«. Priročnik Vodnik za bralca po raziskavi PIAAC (zdaj tudi v slovenskem prevodu) poudarja, da se v kontekstu raziskave ni skušalo ločiti kompetence in spretnosti, termina sta $\mathrm{v}$ mednarodnih poročilih OECD rabljena kot sopomenki. Oba se nanašata na zmožnost ali sposobnost posameznika, da deluje situaciji primerno. Oba vključujeta uporabo znanja (eksplicitnega in/ali skritega), uporabo orodja, kognitivne in praktične strategije in rutine, oba tudi predpostavljata prepričanja, dispozicije in vrednote (npr. drže). Spretnosti (kompetence) se vedno da razbiti na manjše in bolj specifične spretnosti (ali kompetence) ali združiti v splošnejše spretnosti (ali kompetence). V Sloveniji je obveljal dogovor, ki so ga predlagali raziskovalci, da se razumevanju tega, kar je raziskava neposredno merila, približamo $s$ termini besedilne spretnosti, matematične spretnosti in spretnosti reševanja problemov v tehnološko bogatem okolju. 
Raziskava je nastala na podlagi PISE, s katero ocenjujemo uspehe mladih. Dovolj je že izkušnja, da potrdimo, da so spretnosti, ki jih mladi pridobijo med izobraževanjem, drugačne kot spretnosti, ki jih razvijemo v odrasli dobi. V družbi, ki je bogata z informacijami in v kateri so informacije v obliki besedila (natisnjene ali digitalne) splošno navzoče, je sposobnost branja in odzivanja na podlagi besedilnih informacij bistvena. Nizozemski raziskovalec zgodovine knjige in branja Adrian van de Weel po drugi strani meni, da digitalni mediji »oblikujejo nove oblike pismenosti, na katere učitelji, profesorji in drugi izobraževalci nimamo skoraj nobenega vpliva. Tudi zato, ker se preveč oklepamo stare kulture tiska in ne razumemo, da bi morali temeljne izobraževalne vrednote ohraniti tudi $\mathrm{v}$ digitalni dobi. Ustvariti je treba razmere, v katerih bo mogoče učence, kljub tehnološkim spremembam, naučiti logičnega razmišljanja, argumentacije in kritičnega vrednotenja informacij.«(Sobotna priloga, 6. junij 2015)

$\mathrm{V}$ preteklosti so se spretnosti in kompetence enačile s formalnimi kvalifikacijami, ki so jih ljudje pridobili v določenem obdobju svojega življenja. Izobrazba pa je le približek preteklega potenciala. PIAAC meri spretnosti neposredno in pomaga razložiti, kako so ljudje spretnosti pridobivali in izgubljali, kar se je lahko zgodilo zunaj obdobja, v katerem so pridobili prvotne kvalifikacije. Raziskava PIAAC upošteva, česa se posamezniki naučijo na delovnem mestu in priložnostno skozi vse življenje, ter tudi to, kar posamezniki lahko pozabijo, ko se starajo. Neposredna merjenja spretnosti upoštevajo razlike v kakovosti izobraževanja in usposabljanja, ki so ju bili deležni odrasli, tako v državah kot med državami. Raziskava spretnosti odraslih si ne prizadeva samo opisati ravni in porazdelitve zmožnosti, ki jih meri, temveč tudi zagotoviti informacije o dejavnikih, povezanih s pridobivanjem, ohranjanjem ter razvijanjem teh spretnosti in njihovimi rezultati.

Po pričakovanjih OECD in Evropske komisije bo ta obsežna zbirka podatkov, zbranih v PIAAC, med drugim omogočila: bolj celostno merjenje zalog človeških virov; razkrila obseg, v katerem se spretnosti posameznikov dejansko uporabljajo pri delu; ugotovila, kakšno vlogo imajo spretnosti pri izboljševanju možnosti na trgu delovne sile; izboljšala razumevanje trga delovne sile ter družbenih donosov v izobraževanju in usposabljanju; pomagala vladam bolje razumeti, kako sistemi izobraževanja in usposabljanja lahko gojijo te spretnosti; pomagala vladam prednostno razvrstiti vlaganja omejenih virov v izobraževanje in usposabljanje ter prispevala k vzpostavljanju strateškega partnerstva za udejanjanje politik.

Raziskavo PIAAC v številnih primerih izvajajo in financirajo ministrstva za izobraževanje in delo, zato je vedno vključen ekonomski vidik, za katerega je zanimivo razmerje med spretnostmi, zaposlitvenimi možnostmi in blaginjo posameznika ter družbe. Enako pomemben pa je tudi družbeni vidik, ki bistveno širi obzorja raziskave, preučujejo se drugi vidiki življenja, na primer povezave med spretnostmi in družbenim udejstvovanjem, pri čemer se ugotavlja, da tisti ljudje, ki imajo boljše spretnosti, v sebi vidijo akterje, verjamejo, da lahko vplivajo na delovanje družbe. Raziskava ima kljub izvorno neoliberalističnim pogledom enako močno humanistično noto, saj v enaki meri zagovarja stališče, da je družba dolžna zagotoviti svojim odraslim članom razvoj njihovih spretnosti. Morda 
ne bodo vsi segli po enakih izobrazbenih priložnostih, morajo pa vsi razviti svoj polni potencial.

V Sloveniji smo si s projektom zastavili ambiciozne cilje. Ključna posebnost slovenske raziskave je, da cilji projekta ne vključujejo zgolj ciljev OECD, temveč tudi analitično-aplikativne nacionalne cilje. Projekt, ki ga izvaja konzorcij partnerjev s petih ustanov (Andragoški center Slovenije, Statistični urad Slovenije, Fakulteta za družbene vede, Oddelek za pedagogiko in andragogiko na Filozofski fakulteti, Ekonomska fakulteta, vse z Univerze v Ljubljani), je od vsega začetka sestavljen iz dveh ključnih delov: zbiranja podatkov na terenu in analitično-aplikativnega dela.

V letih 2013 in 2014 je slovenski konzorcij PIAAC izpeljal pilotno in glavno raziskavo PIAAC, v katerih je sodelovalo prek 6.500 odraslih med 16. in 65. letom starosti. Obenem so se pripravljale konceptualne in teoretske podlage za tematske študije in analize. Tematske študije in analize snuje interdisciplinarna skupina raziskovalcev, ki prihajajo $\mathrm{z}$ vseh partnerskih ustanov v konzorciju. Posamezni raziskovalci v konzorciju PIAAC se osredotočajo na ugotavljanje povezav med kompetencami in sedanjimi potrebami na trgu dela, preučujejo sovplivanje kompetenc na socialne in ekonomske dosežke posameznika in družbe ter ocenjujejo, v kolikšni meri izobraževalni sistem zagotavlja pridobivanje ustreznih kompetenc tako pri odraslih kot tudi pri mladini in kakšno je stanje pri ranljivih skupinah prebivalstva.

Andreas Schleicher (OECD), ki je maja letos v Ljubljani plenarno nagovoril udeležence zaključne konference projekta v Sloveniji, je med drugim povedal, da nas pri podatkih najprej preseneti dejstvo, da so države, kjer imajo vsi odrasli odlične spretnosti. Spretnosti torej niso le prirojene, niso le stvar predispozicije, niso izključno stvar nadarjenosti. So države, kjer vsi odrasli, tako revni kot bogati, razvijejo dobre spretnosti. To pomeni, da lahko na spretnosti vplivamo s politikami in praksami. Družba lahko razvije potencial spretnosti vseh prebivalcev. Vlade so torej tiste, ki morajo razmisliti o ravnovesju med spretnostmi, ki jih potrebujemo danes, in tistimi, ki jih bodo potrebovali mladi jutri.

Tematska številka revije vsebuje štiri od skupaj devetih tematskih študij, ki jih pripravlja raziskovalna skupina PIAAC v Sloveniji. Prispevek S. Kump z naslovom Vpliv izobrazbe in spretnosti starejših na individualno in družbeno blaginjo se ukvarja $\mathrm{z}$ analizo mednarodnih podatkov o vplivu izobrazbe in spretnosti na področju aktivnega državljanstva, socialne kohezije in osebnega razvoja na vzorcu starostne skupine 55-65 let. Ugotovitve analize $\mathrm{v}$ izbranih državah potrjujejo povezavo med stopnjo izobrazbe in spretnosti starejših odraslih z individualno in družbeno blaginjo, čeprav je povezanost v nekaterih državah močnejša. Prispevek S. Jelenc Krašovec Izobraževanje in usposabljanje starejših delavcev - mednarodna primerjava analizira vlogo in pomen izobraževanja in usposabljanja starejših delavcev z vidika učinkov na delovnem mestu. Študija na podlagi primerjave med državami ugotavlja, da se vplivi izobraževanja in usposabljanja (starejših) delavcev kažejo na različnih ravneh pojavnosti, in sicer kot znanje, spretnosti, vrednote, vedenje posameznikov, po drugi strani pa se učinki kažejo tudi na organizacijski ravni. Rezultati obeh študij bodo tudi s pomočjo slovenskih podatkov lahko podprli prizadevanja ustvariti 
tako okolje, da bo v sodobnih družbah, še posebej v tistih, ki se starajo, lahko vsak prispeval in delal, kot mu narekuje njegov potencial. Že dosedanje ugotovitve razkrivajo, da se starejši delavci zdaj v povprečju premalo vključujejo v izobraževanje in usposabljanje, kar ni le posledica varčevanja podjetij, temveč tudi minimalnih spodbud države za zaposlovanje, pa tudi izobraževanje in usposabljanje starejših delavcev.

Raziskava PISA razkriva kakovost šolskih sistemov, raziskava PIAAC pa dokazuje, da je učenje vseživljenjski proces. Ob tem dobro meri tudi dejavnike, povezane s politiko in možnostmi za učenje, ki so na voljo skozi vse življenjsko obdobje. J. Muršak in M. Radovan sta v prispevku Vpliv neformalnega izobraževanja na razvoj spretnosti in kompetenc na podlagi primerjave mednarodnih podatkov pokazala na velik pomen, ki ga ima vključevanje v neformalno izobraževanje za dosežke na vseh treh področjih, kjer je raziskava merila stopnje doseženih spretnosti. Primerjava med državami je prinesla pomembno ugotovitev, in sicer se je pri nekaterih izmerjenih spretnostih izkazalo, da so v vseh primerih dosegali boljše rezultate tisti, ki so bili vključeni v neformalno izobraževanje, ki ni bilo povezano s potrebami dela in poklica. Če se bo ugotovitev potrdila tudi na slovenskih podatkih, bo to pomembna iztočnica $\mathrm{v}$ zagovor neformalnega izobraževanja, ki ni vezano na poklic in delo. Med drugim pa bodo aktualna tudi vprašanja o vrednotenju in priznavanju tega neformalnega izobraževanja.

Zadnji prispevek Digitalna pismenost in reševanje problemov v tehnološko bogatih okoljih v okviru tematike sta prispevali V. Dolničar in M. Mrzel. V njem pojasnjujeta koncept digitalnih spretnosti in reševanja problemov $\mathrm{v}$ tehnološko bogatih okoljih in ga raziskujeta s pomočjo empiričnih podatkov, pridobljenih v mednarodni študiji PIAAC. Primerjalni rezultati v izbranih državah so potrdili, da imata največji vpliv na stopnjo reševanja problemov $\mathrm{v}$ tehnološko bogatih okoljih starost in izobrazba, kar potrjujejo tudi rezultati drugih raziskav. Avtorici končujeta prispevek s predlogom za oblikovanje politik na področju digitalnih spretnosti s poudarkom na problematičnem položaju ranljivih skupin, ki jih zaznamujeta neustrezna izobrazba in starost.

Izbrane študije, predstavljene $\mathrm{v}$ tej številki revije, odstirajo določene nove poglede na položaj nekaterih družbenih skupin, na vlogo izobraževanja in spretnosti, že na podlagi mednarodnih primerjav in na podlagi poprejšnjih študij. Stojimo na stališču, da so nujno potrebne primerjalne analize, da ugotovimo, ali so slovenske težave občečloveške ali posledica določenih praks in politik. Ko se poglobimo v podatke in jih povežemo z drugimi raziskavami, lahko odkrijemo, katere politike in prakse so drugim državam pomagale.

$\mathrm{V}$ času, ko bomo še preučevali slovenske podatke, pa se že kažejo nekateri novi izzivi pri približevanju študij PISA in PIAAC, in sicer je v načrtu več opcij, na primer razvoj psihometričnih povezav na enem ali več področjih merjenja, razmišlja se tudi o vključitvi 15-letnikov v raziskavo PIAAC v enem od naslednjih krogov raziskave, kar bi omogočilo neposredne primerjave rezultatov med študijami.

Za zaključek morda še misel prej omenjenega raziskovalca zgodovine knjige in branja. A. van der Weel pravi še, »da je znanje, ki ga potrebujemo za retoriko, argumentacijo in 
kritično razmišljanje, še vedno mogoče najti v knjigah in ga ponotranjiti s poglobljenim branjem. Brez teh veščin smo zelo slabo opremljeni za življenje v sodobnih demokracijah, saj ne znamo prepoznati politične propagande in populizma, ki namesto argumentov uporabljata manipulacijo in čustva.« (prav tam) Misel zlahka prenesemo na izobraževanje odraslih v digitalni dobi in ob tem opozorimo, da bo po objavi rezultatov raziskave PIAAC v Sloveniji poleg razvoja spretnosti odraslih nujno potrebno premisliti o drugih razsežnostih in namenih izobraževanja odraslih. 